\title{
Potential bioethanol and biogas production using lignocellulosic biomass from winter rye, oilseed rape and faba bean
}

\author{
Anneli Petersson*, Mette H. Thomsen, Henrik Hauggaard-Nielsen, Anne-Belinda Thomsen \\ Risø National Laboratory, P.O. Box 49, DK-4000 Roskilde, Denmark
}

Received 14 February 2007; received in revised form 19 April 2007; accepted 1 June 2007

Available online 26 July 2007

\begin{abstract}
To meet the increasing need for bioenergy several raw materials have to be considered for the production of e.g. bioethanol and biogas. In this study, three lignocellulosic raw materials were studied, i.e. (1) winter rye straw (Secale cereale L), (2) oilseed rape straw (Brassica napus L.) and (3) faba bean straw (Viciafaba L.). Their composition with regard to cellulose, hemicellulose, lignin, extractives and ash was evaluated, as well as their potential as raw materials for ethanol and biogas production. The materials were pretreated by wet oxidation using parameters previously found to be optimal for pretreatment of corn stover $\left(195^{\circ} \mathrm{C}, 15 \mathrm{~min}_{2} 2 \mathrm{gl}^{-1} \mathrm{Na}_{2} \mathrm{CO}_{3}\right.$ and $12 \mathrm{bar}$ oxygen). It was shown that pretreatment was necessary for ethanol production from all raw materials and gave increased biogas yield from winter rye straw. Neither biogas productivity nor yield from oilseed rape straw or faba bean straw was significantly affected by pretreatment. Ethanol was produced by the yeast Saccharomyces cerevisiae during simultaneous enzymatic hydrolysis of the solid material after wet oxidation with yields of $66 \%, 70 \%$ and $52 \%$ of theoretical for winter rye, oilseed rape and faba bean straw, respectively. Methane was produced with yields of $0.36,0.42$ and $0.441 \mathrm{~g}^{-1}$ volatile solids for winter rye, oilseed rape and faba bean straw, respectively, without pretreatment of the materials. However, biogas productivity was low and it took over 50 days to reach the final yield. It could be concluded that all three materials are possible raw materials for either biogas or ethanol production; however, improvement of biogas productivity or ethanol yield is necessary before an economical process can be achieved.
\end{abstract}

(C) 2007 Elsevier Ltd. All rights reserved.

Keywords: Ethanol; Biogas; Lignocellulosic biomass; Winter rye (Secale cereale L.); Oilseed rape straw (Brassica napus L.); Faba bean straw (Viciafaba L.)

\section{Introduction}

Increased concern for the security of oil supply and the negative impact of fossil fuels on the environment, particularly greenhouse gas emissions, has put pressure on society to find renewable alternatives [1]. Bioenergy from renewable resources is already today a viable alternative to fossil fuels; however, to meet the increasing need for bioenergy several raw materials have to be considered. Lignocellulose is the most abundant organic material on earth and is therefore a promising raw material for bioenergy production [2].

Bioethanol can be produced from e.g. sugars, starch and various lignocellulosic materials such as straw, wood and waste [3]. While the production of ethanol from sugars and

\footnotetext{
${ }^{*}$ Corresponding author. Tel.: +4546774195 ; fax: +4546774122 .

E-mail address: Anneli.Petersson@risoe.dk (A. Petersson).
}

starch is more straightforward, ethanol production from lignocellulose creates additional technical challenges, such as a need for pretreatment. Lignocellulosic materials contain cellulose and hemicellulose that are bound together by lignin. Cellulose and hemicellulose are both polymers built up by long chains of sugar monomers, which after pretreatment and hydrolysis, can be converted into ethanol by microbial fermentation. Different pretreatment methods exist, such as wet oxidation [4,5], that is used in this study, as well as other methods such as steam explosion [6]. The aim of the pretreatment is to open up the lignocellulosic structure to enable enzymatic hydrolysis. In enzymatic hydrolysis, the monomeric sugars bound in cellulose and hemicellulose are released and become available for conversion into ethanol. The most commonly used microorganism for ethanol production is ordinary baker's yeast, Saccharomyces cerevisiae. In the pretreatment process, some inhibitors are formed [7] and S. cerevisiae is one of 
the most inhibitor-tolerant microorganisms used for the conversion [8]. However, it can only convert the hexoses, such as glucose and mannose, and not the pentoses, such as xylose and arabinose, that are found in the hemicellulose part of the straw.

An alternative, or in some processes a secondary production, to bioethanol production is the production of biogas. Biogas consists mainly of methane and carbon dioxide, and is the product after anaerobic digestion of a wide range of biomass resource like e.g. organic fraction of municipal solid waste, sewage sludge, industrial effluents, fruit and vegetable solid waste, leaves, grasses, woods, terrestrial weeds, aquatic biomass [9]. Pretreatment techniques have been evaluated for biogas production, but are not always used. The available pretreatment methods for biogas production can be divided into five groups: alkali or acid treatment, predigestion, thermochemical, ultrasonic and ensilage of feed [10]. In biogas production, usually $7-9 \%$ solids are inoculated with e.g. digested sludge from a running biogas plant, municipal digester or animal manure [10]. Suitable raw materials for biogas production have a high content of available carbohydrates, obviously, but also a high raw material $\mathrm{N}$ content increases gas production [11]. Faba bean, as an atmospheric $\mathrm{N}_{2}$-fixing leguminous species, have a higher straw $\mathrm{N}$ content than rye and oilseed rape, with oilseed rape usually having higher $\mathrm{N}$ content than cereals like rye $[12,13]$.

In this study, wet oxidation was used as the pretreatment method. In this method the straw is suspended in a water solution and heated under pressure in the presence of oxygen. It was presented in the early 1980s as an alternative to steam explosion [5]. Wet oxidation has been studied on several raw materials such as wheat straw [4] and corn stover [14]. Usually the method has been studied for ethanol production, but it has also been used for increased biogas production from e.g. newspaper waste [15].

Substitution of fossil fuels by crop biomass requires the right selection of plant species with high site suitability, an ecologically benign farming system and high yields [16]. The yield of bioenergy is limited by land and to maximize gain the energy inputs must be minimized [17]. Some crops, especially cereals like winter rye (Secale cereale L.) and crucifers like oilseed rape (Brassica napus L.) are strongly dependent on soil nitrogen $(\mathrm{N})$ availability and therefore their cultivation is expensive from a fossil energy point of view [16]. However, in areas with high levels of animal manure, a crop with high $\mathrm{N}$ demand is important to include in the rotation to limit $\mathrm{N}$ leaching [18]. Introduction of a higher extent of legumes like faba bean (Viciafaba L.) benefits the farming system via biological $\mathrm{N}_{2}$-fixation inputs and by its effect as a break crop for rotational cereal diseases, potentially reducing the need for pesticides $[19,20]$.

In this study, winter rye straw, oilseed rape straw and faba bean straw were characterized, wet oxidized and used for ethanol and biogas production with the aim of enabling the evaluation of the potential of using these raw materials for bioenergy production.

\section{Materials and methods}

\subsection{Raw materials}

Three raw materials were compared: (1) winter rye straw, (2) oilseed rape straw and (3) faba bean straw. The crops were cultivated during summer (2005) in the experimental fields of Risø National Laboratory, Denmark $\left(55^{\circ} 41^{\prime} \mathrm{N}\right.$, $\left.12^{\circ} 05^{\prime} \mathrm{E}\right)$. The crops were harvested during August 2005 at full maturity and separated in crop and weed fractions. The samples were dried at $70^{\circ} \mathrm{C}$ to constant weight and stored at room temperature until use a year later. The yield from $1 \mathrm{~m}^{2}$ was for winter rye $0.62 \mathrm{~kg}(0.26 \mathrm{~kg}$ straw $)$, oilseed rape $0.67 \mathrm{~kg}(0.46 \mathrm{~kg}$ straw and empty pods) and faba bean $0.40 \mathrm{~kg}(0.32 \mathrm{~kg}$ straw and empty pods). The grain was separated after threshing. Only the pure winter rye straw fraction was used, whereas for both oilseed rape and faba bean empty pods were included in the straw fraction. The three straw samplings were milled to a size of less than $2 \mathrm{~mm}$ prior to pretreatment and further analysis.

\subsection{Pretreatment}

The three materials were all pretreated by wet oxidation using conditions that previously have been shown to be optimal for corn stover pretreatment: $195^{\circ} \mathrm{C}, 2 \mathrm{gl}^{-1}$ $\mathrm{Na}_{2} \mathrm{CO}_{3}, 12$ bar $\mathrm{O}_{2}, 15 \mathrm{~min}$ [14]. Similar parameters have also been found optimal for wet oxidation of wheat straw [7]. The wet oxidations were performed in a loop autoclave constructed at Risø National Laboratory using 6\% dry material (DM). Four wet oxidations were run for each material, and for two of the experiments the solid and liquid fractions were separated by filtration. This was done to enable separate analysis of the fractions as well as enabling estimation of the effect of filtrate on ethanol production. For the other two experiments, for each material, the wet oxidized material was kept in one fraction and used for the biogas experiments. Pretreated materials were stored at $-20^{\circ} \mathrm{C}$ until further analysis and use. The filter cakes were dried in a climate cabinet at $20^{\circ} \mathrm{C}$ and $65 \%$ relative humidity.

\subsection{Enzymatic hydrolysis of solid fraction}

The enzymatic convertibility of the solid fraction after pretreatment was determined for the three materials as well as the convertibility of the untreated raw materials. Enzymatic hydrolysis took place at $50^{\circ} \mathrm{C}, \mathrm{pH} 4.8$, with $2 \% \mathrm{DM}$ and an enzyme load of $30 \mathrm{FPU} \mathrm{g}^{-1} \mathrm{DM}$. The enzyme used was Cellubrix L. (Novozymes, Denmark) and the amounts of hydrolyzed sugars were determined by HPLC (see Section 3 for further details). The experiments were carried out in triplicates for each solid pretreatment fraction, and in triplicate for each raw material. 


\subsection{Simultaneous saccharification and fermentation}

After wet oxidation, $8 \mathrm{~g}$ DM of the solid fraction (filter cake) was mixed with $60 \mathrm{ml}$ of either filtrate or water (pH 4.8) in $250 \mathrm{ml}$ fermentation flasks. All experiments were done in duplicate. Liquefaction was performed at $50{ }^{\circ} \mathrm{C}$ with an enzyme (Cellubrix L.) load of $15 \mathrm{FPU} \mathrm{g}^{-1}$ DM for $24 \mathrm{~h}$. After cooling to room temperature, $20 \mathrm{FPU} \mathrm{g}^{-1} \mathrm{DM}$ enzymes (Cellubrix L.), $0.2 \mathrm{~g}$ dry commercial yeast (Malteserkors tørgær, De Danske Spritfabrikker A/S, Denmark) and $0.2 \mathrm{ml}$ urea (24\%) were added. The headspace in the flasks was flushed with $\mathrm{N}_{2}$, and the flasks were equipped with yeast locks filled with glycerol. The flasks were then incubated at $32^{\circ} \mathrm{C}$ and the amount of produced ethanol was determined as weight loss caused by $\mathrm{CO}_{2}$ liberation. The final ethanol concentration was determined by HPLC (see Section 3 for further details).

\subsection{Biogas}

The measurement of biogas potential for the raw material and the wet oxidized material was done in duplicate according to Hansen et al. [21], though smaller flasks and less material was used. Methane production was measured in $100 \mathrm{ml}$ serum flasks containing $0.3 \mathrm{~g}$ dry straw $(<2 \mathrm{~mm})$ in $5 \mathrm{ml}$ water or $5 \mathrm{ml}$ wet oxidized material, corresponding to $0.3 \mathrm{~g}$ of dry straw before pretreatment. The inoculum was taken from a biogas plant (Nysted Biogas Amba, Kettinge, Denmark) where manure is used as raw material for biogas production at $42{ }^{\circ} \mathrm{C}$. The inoculum had a volatile solid content of $69 \%$ and $20 \mathrm{ml}$ inoculum was added to each flask. The flasks were flushed with nitrogen, sealed with a rubber septum and placed in a shaker bath at $42^{\circ} \mathrm{C}$ and stirring of $100 \mathrm{rpm}$.

\section{Analysis methods}

\subsection{Dry matter and ash content}

Duplicates of $0.5 \mathrm{~g}$ solid material or $10 \mathrm{ml}$ of liquid sample were dried at $105^{\circ} \mathrm{C}$ overnight to determine the dry weight. The samples were thereafter heated to $550^{\circ} \mathrm{C}$ for $3 \mathrm{~h}$ to determine the ash content.

\subsection{Analysis of carbohydrates in solid fraction}

The amounts of extractives were determined in the raw materials by extraction in boiling ethanol for $24 \mathrm{~h}$ prior to hydrolysis. To quantify the sugar polymers in the raw material and the solid fraction after wet oxidation, a twostep acid hydrolysis was performed. The first hydrolysis step was performed at $30^{\circ} \mathrm{C}$ for $60 \mathrm{~min}$ with $1.5 \mathrm{ml}$ of $\mathrm{H}_{2} \mathrm{SO}_{4}(72 \%)$ for $0.16 \mathrm{~g}$ DM. Then $42 \mathrm{ml}$ water was added and the second step was performed at $121^{\circ} \mathrm{C}$ for $60 \mathrm{~min}$. The hydrolysate was filtered and the dried filter cake subtracted for ash content is reported as Klason lignin.

\subsection{Analysis of carbohydrates in liquid fraction}

In order to quantify the sugar content in the liquid fraction, a weak hydrolysis was performed at $121^{\circ} \mathrm{C}$ for 10 min using $4 \% \mathrm{H}_{2} \mathrm{SO}_{4}$, in duplicate. The concentrations of sugar monomers were determined by HPLC, as described below.

\subsection{HPLC analysis}

The amounts of released sugar monomers in the hydrolysate as well as concentrations of ethanol, malic acid, succinic acid, glycolic acid, formic acid and acetic acid were determined by HPLC (Shimadzu) using a Rezex ROA column (Phenomenex) at $63{ }^{\circ} \mathrm{C}$ and $4 \mathrm{mM} \mathrm{H}_{2} \mathrm{SO}_{4}$ as eluent at a flow rate of $0.6 \mathrm{ml} \mathrm{min}^{-1}$. A refractive index detector (Shimadzu Corp., Kyoto, Japan) was used.

\subsection{Methane analysis}

The methane content in the flasks was measured regularly during 67 days. For every measurement, $0.2 \mathrm{ml}$ from each flask was taken with a syringe equipped with a pressure lock. To avoid high pressure in the flasks the gas was, when considered necessary, released just after analysis of the gas and thereafter the methane content was measured once again and the loss of methane taken into account. The methane content of the samples was analyzed on a Shimadzu GC-14 equipped with a Porapak T column $\left(110^{\circ} \mathrm{C}\right)$ and a flame ionization detector $\left(200^{\circ} \mathrm{C}\right)$. The carrier gas was $\mathrm{He}$ at $30 \mathrm{ml} \mathrm{min}^{-1}$.

\section{Calculations}

In order to evaluate the pretreatment, the recovery of sugars in the filtrate or the solid was calculated according to Eq. (1). The yields after enzymatic hydrolysis were calculated according to Eq. (2) for cellulose and Eq. (3) for hemicellulose. Product yields for ethanol and biogas are reported as $\mathrm{g}$ product per $100 \mathrm{~g}$ raw material or as liter per g volatile solids (VS) for biogas yield. The amount of biogas resulting from the inoculum (measured in bottles only containing inoculum) was subtracted from the total biogas formed before the yield was calculated.

$$
\begin{aligned}
& \text { Recovery }_{\text {filtrate/solid }} \\
& =\frac{(\text { sugar in filtrate/solid }(\mathrm{g} / 100 \mathrm{~g}))}{(\text { sugar in rawmaterial }(\mathrm{g} / 100 \mathrm{~g}))} 100 \%,
\end{aligned}
$$

$$
\begin{aligned}
& \text { Hydrolysis yield } \text { cellulose }_{\text {a }} \\
& \qquad=\frac{\left(\text { mass }_{\text {glucose }} \text { after enzymatic hydrolysis } \times 0.9\right)}{\left(\text { mass }_{\text {cellulose }} \text { in raw material }\right)} 100 \%
\end{aligned}
$$


and

Hydrolysis yield ${ }_{\text {hemicellulose }}$

$$
=\frac{\left(\begin{array}{c}
\text { mass }_{\mathrm{xylose}+\text { arabionose }} \text { after enzymatic } \\
\text { hydrolysis } \times 0.88
\end{array}\right)}{\left(\text { mass }_{\text {hemicellulose }} \text { in raw material }\right)} 100 \% \text {. }
$$

The theoretical yield of ethanol was based on the assumption that all glucose found in the raw material could be converted into ethanol, with a yield of $0.51 \mathrm{~g}$ ethanol g $\mathrm{g}^{-1}$ glucose. The theoretical yield of methane was calculated assuming that the VS in the raw material had the formula $\mathrm{CH}_{2} \mathrm{O}$, which is the case for all sugars after hydrolysis. It was further assumed that the VS were stoichiometrically converted into methane and carbon dioxide.

\section{Results}

\subsection{Raw material composition}

Compositions of the three raw materials are shown in Table 1. All three materials evaluated in this study can potentially be used for bioethanol by conversion of the sugar monomers glucose and xylose. Especially winter rye has high contents of both glucan and xylan $(40.8 \%$ and $22.3 \%$, respectively) (Table 1 ), which are higher than the amounts found in wheat straw $(30.4 \%$ and $18.4 \%$ for glucan and xylan, respectively) [22]. Oilseed rape and faba bean straw both contain less glucan and xylan than winter rye and wheat straw. By the analysis done, only $4.9 \%$ of the winter rye straw was not accounted for. For the others, around $20 \%$ of the materials were not accounted for. Biogas can potentially be produced from VS in the materials. VS is the amount of dry matter that is not ash. VS for the materials are thus $95 \%, 90 \%$ and $92 \%$ of DM for winter rye straw, oilseed rape straw and faba bean straw, respectively.

Table 1

Chemical composition of the lignocellulosic raw material used in this study

\begin{tabular}{lccc}
\hline & Winter rye & Oilseed rape $^{\mathrm{a}}$ & Faba bean $^{\mathrm{a}}$ \\
\hline Dry weight & 92.9 & 90.7 & 92.1 \\
\hline \% of DW & & & \\
Glucan & 40.8 & 27.3 & 28.4 \\
Xylan & 22.3 & 15.0 & 12.4 \\
Galactan & 1.2 & 2.7 & 4.0 \\
Mannan & ND & 2.0 & 2.2 \\
Arabinan & 2.6 & 2.2 & 1.8 \\
Klason & 16.1 & 14.2 & 14.4 \\
Ash & 5.1 & 9.6 & 7.9 \\
Extractives & 7.1 & 10.1 & 8.8 \\
Residual & 4.9 & 17.0 & 20.2 \\
\hline
\end{tabular}

ND, not detected.

${ }^{\mathrm{a}}$ For oilseed rape and faba bean, the lignocellulosic straw component included empty pods.

\subsection{Pretreatment and sugar recovery}

In this study, the recovery for cellulose sugars (glucose and mannose) were $87 \%, 89 \%$ and $92 \%$ for winter rye straw, oilseed rape straw and faba bean straw, respectively, while the recovery for hemicellulose sugars were $66 \%, 60 \%$ and $69 \%$, respectively (Fig. 1). During wet oxidation, part of the hemicellulose is solubilized and a larger part of the hemicellulose will end up in the liquid phase than in the solid phase, while the cellulose to a larger extent will remain in the solid fraction (Fig. 1).

\subsection{Enzymatic hydrolysis}

Wet oxidation clearly makes the material much more accessible to enzymatic hydrolysis (Fig. 2). The sugar yields after enzymatic hydrolysis were $49 \%, 58 \%$ and $43 \%$ for winter rye, oilseed rape and faba bean straw, respectively, for wet oxidized materials. For raw materials, the yields of cellulose were only $9 \%, 14 \%$ and $28 \%$ for winter rye, oilseed rape and faba bean straw, respectively.

\subsection{Ethanol production}

Simultaneous saccharification and fermentation (SSF) was performed on the raw materials and on wet oxidized fibers suspended either in the filtrate or water (Fig. 3). The ethanol yield and productivity on the raw material were rather low, but were improved by pretreatment of the materials (Fig. 3). This is probably due to a low enzymatic convertibility of the untreated raw materials (Fig. 2). The filtrates were shown to introduce a lag phase on ethanol formation especially for oilseed rape fermentation (Fig. 3).

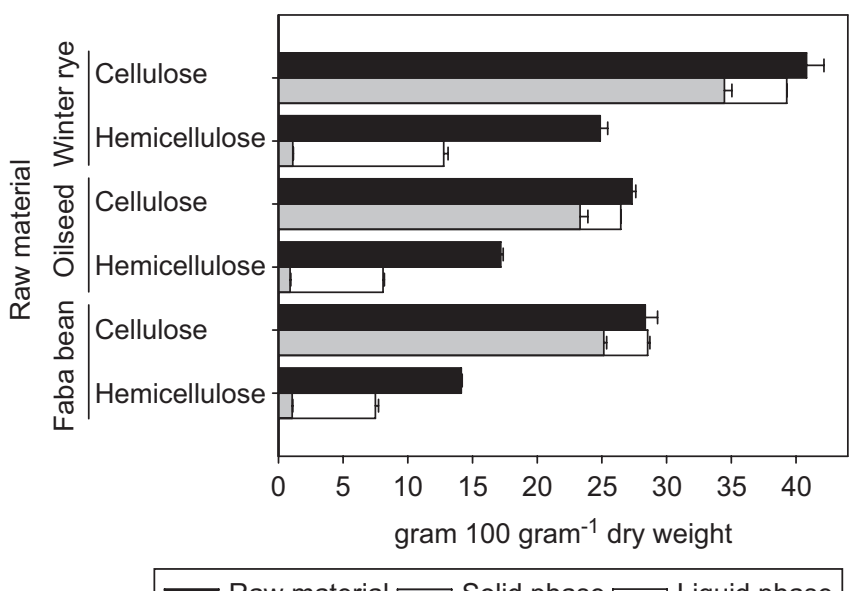

Fig. 1. Cellulose and hemicellulose in $100 \mathrm{~g}$ dry raw material (both black bars) shown together with recovery after wet oxidation of $100 \mathrm{~g}$ dry material. The recovered cellulose and hemicellulose are divided into amounts found in the solid phase (gray bars) and amounts found in the liquid phase (white bars). Average values and standard deviation reported for triplicate measurements. 
The initial ethanol productivity from pretreated oilseed rape straw was $0.91 \mathrm{~g}^{-1} \mathrm{~h}^{-1}$ in water and as low as $0.16 \mathrm{gl}^{-1} \mathrm{~h}^{-1}$ in filtrate. The concentration of acids was shown to be higher for oilseed rape straw filtrate compared

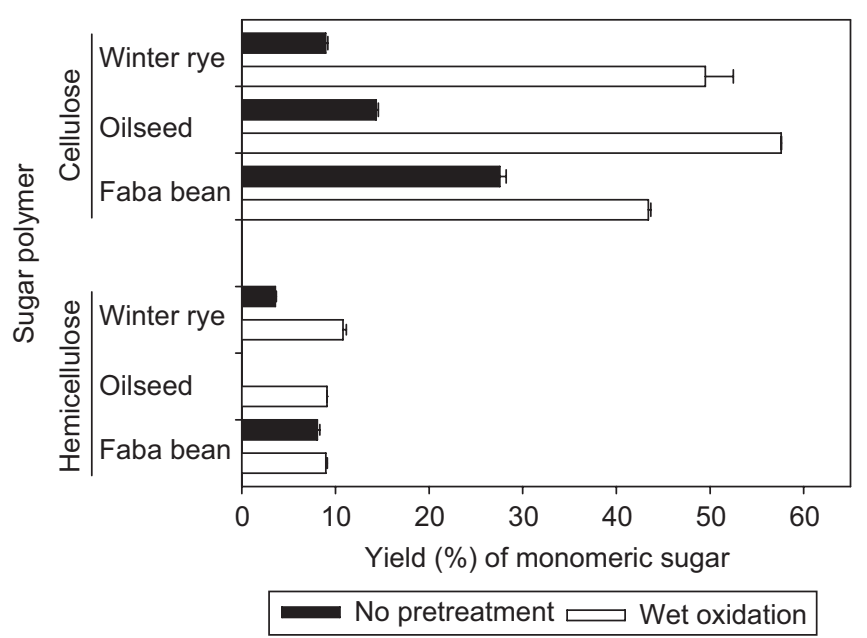

Fig. 2. Yield of monomeric sugars after enzymatic hydrolysis of raw material (black bars) and after enzymatic hydrolysis on wet oxidized (WO) material (white bars). Average values and standard deviation are reported for triplicate measurements. with the other filtrates (Fig. 4). The ethanol yields (Table 2) without filtrate were $66 \%, 70 \%$ and $52 \%$ of the theoretical for winter rye, oilseed rape and faba bean straw, respectively. This is higher than what could enzymatically be converted (which were $49 \%, 58 \%$ and $43 \%$, respectively). $S$. cerevisiae does not consume pentoses such as xylose and therefore xylose, which is released during the enzymatic hydrolysis, accumulated (Fig. 5).

\subsection{Biogas production}

Biogas productivity (Fig. 3) and yield (Table 2) were measured for both untreated raw material and wet oxidized materials. The biogas yields in Table 2 are given in $g$ methane per $100 \mathrm{~g} \mathrm{DM}$, to enable a comparison with ethanol yield. However, biogas yield is often reported as volume of methane per unit weight of VS. The yields were $0.36,0.42$ and $0.44 \mathrm{~m}^{3} \mathrm{~kg}^{-1}$ VS for untreated winter rye, oilseed rape and faba bean straw, respectively. Wet oxidation of the materials only had a significant effect on biogas productivity and yield for winter rye straw. A maximum in productivity was reached after around 20 days for all materials but for untreated winter rye straw, for which the maximum was reached after around 30 days while it took more than 50 days to reach the final yield.
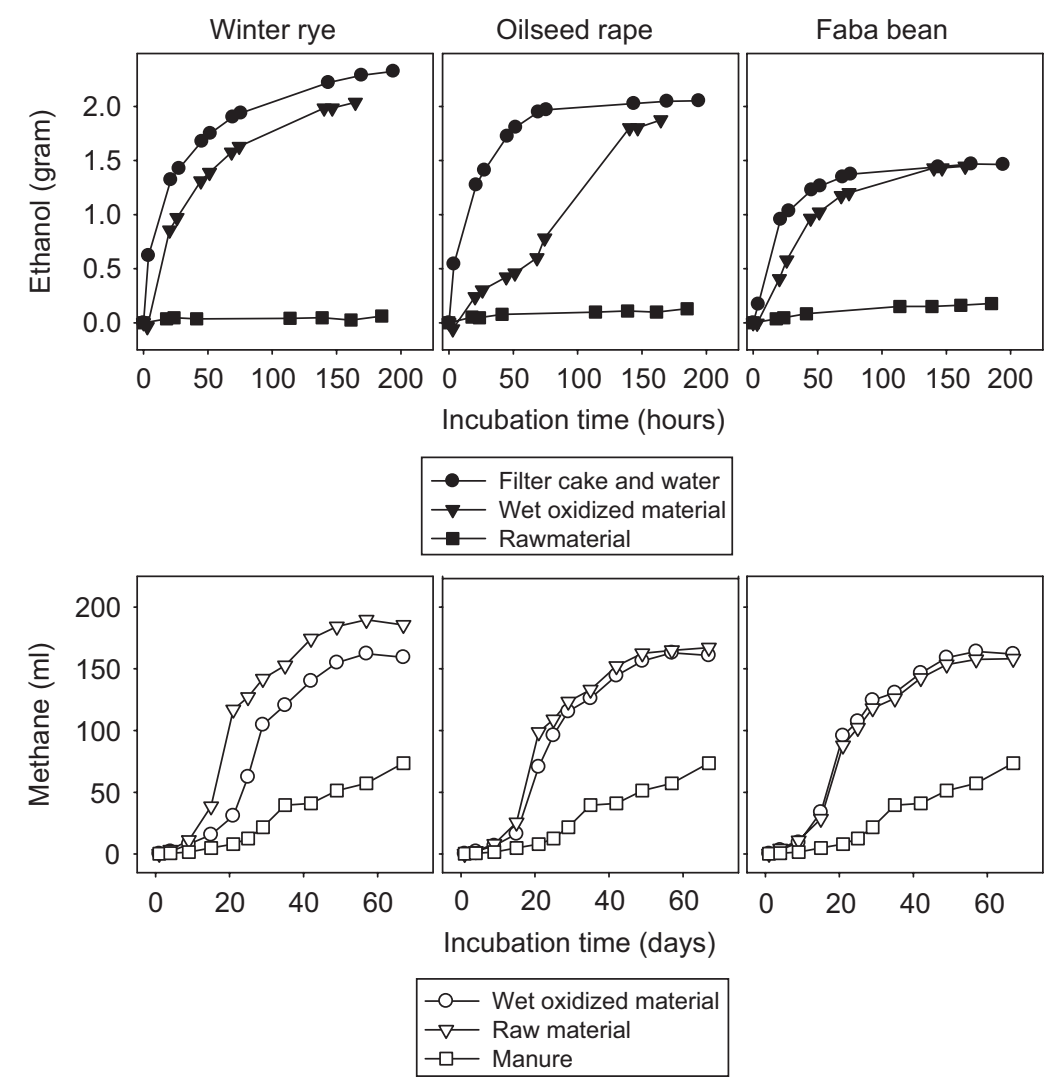

Fig. 3. Ethanol formation (closed symbols) in simultaneous saccharification and fermentation (SSF) of $8 \mathrm{~g}$ filter cake in $60 \mathrm{ml}$ filtrate or with $60 \mathrm{ml}$ water for winter rye, oilseed rape and faba bean straw (upper row). Using the same raw materials, methane formation was measured (open symbols) from $0.3 \mathrm{~g}$ raw material in $5 \mathrm{ml}$ water, or $5 \mathrm{ml}$ wet oxidized material (lower row). The biogas flasks, and the flasks containing only manure, were all inoculated with $20 \mathrm{ml}$ manure. 


\section{Discussion}

Both biogas and ethanol can clearly be produced from the lignocellulosic raw materials evaluated in this study (Fig. 3). For ethanol production, it was necessary to include a pretreatment step in order to increase enzymatic hydrolysis (Fig. 2). However, pretreatment only had a significant effect on the production of biogas from winter rye straw, while biogas productivity and yield were similar for untreated and wet oxidized materials of both oilseed rape straw and faba bean straw. In this study, fixed

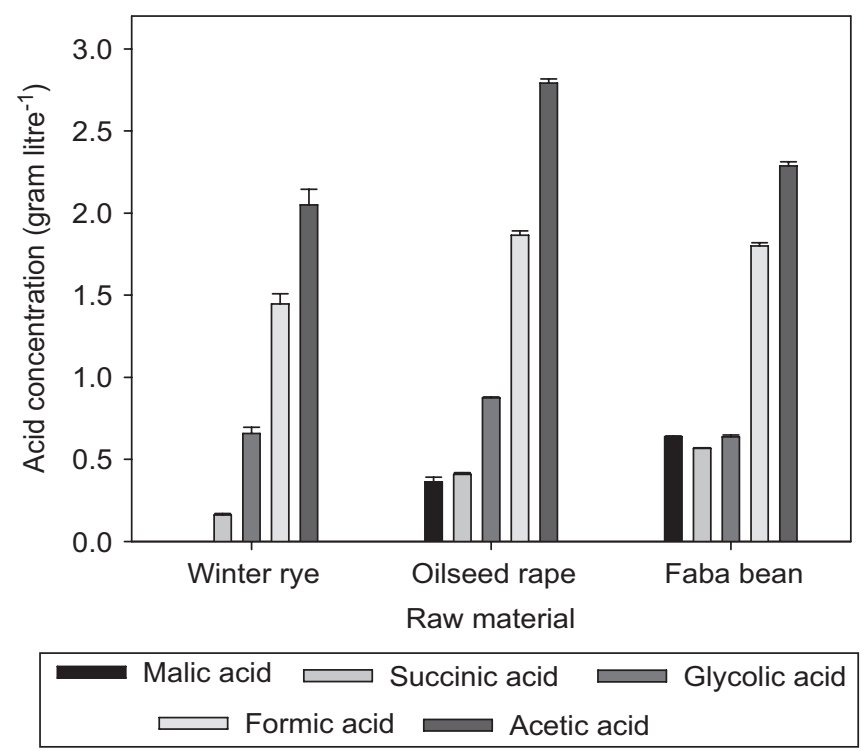

Fig. 4. Concentrations of acids in the pretreated filtrates from straw of winter rye, oil seed rape and faba bean. The materials were wet oxidized at $195^{\circ} \mathrm{C}$ for $15 \mathrm{~min}$ with $2 \mathrm{gl}^{-1} \mathrm{Na}_{2} \mathrm{CO}_{3}$ and 12 bar oxygen and the liquid phases were separated by filtration and analyzed on FtPLC. Average values and standard deviation reported for duplicate measurements. parameters for wet oxidation previously found in optimization of corn stover pretreatment were used [14]. This was done by a screening of the three raw materials, but since winter rye straw, oilseed rape straw and faba bean straw have quite different chemical compositions (Table 1), the pretreatment effect is expected to be improved when optimized separately for each specific raw material and thereby yields and productivities can potentially be increased. Furthermore, inhibitors are partly formed by

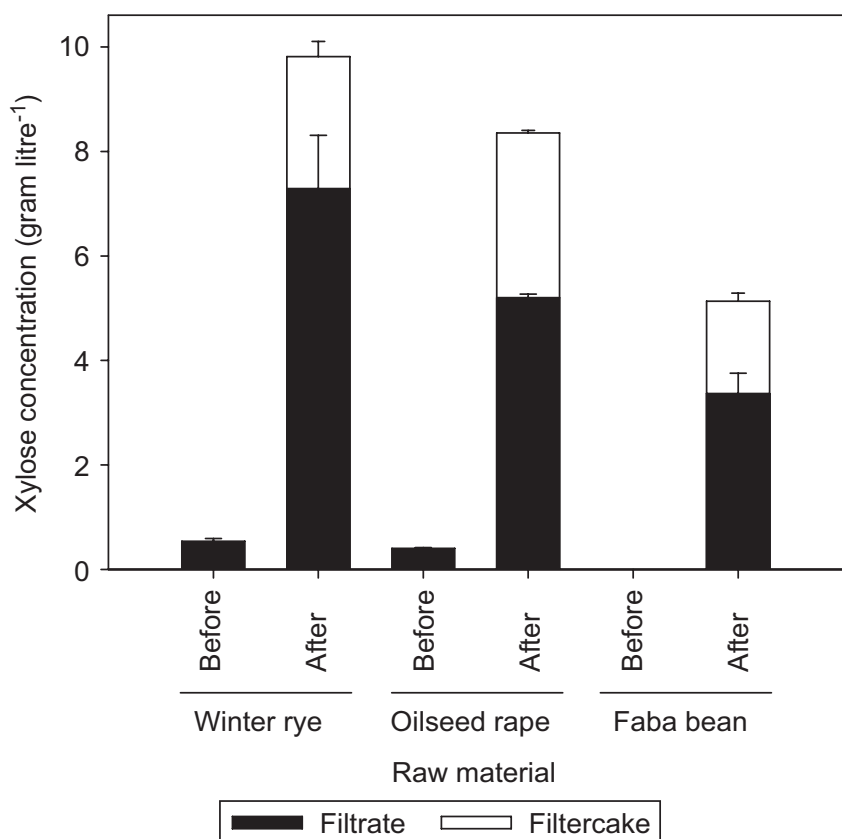

Fig. 5. Xylose concentrations before and after simultaenous saccharification and fermentation (SSF). Xylose concentration in the filtrate (black bars), xylose released as monomers during SSF originating from filtrate (gray bars) and from filter cake (white bars). Average values and standard deviation are reported for duplicate measurements.

Table 2

Bioethanol and methane production determined as yield ( $\left.\mathrm{g}(100 \mathrm{~g} \text { dry raw material })^{-1}\right)$ and percentage of theoretical yield for winter rye, oilseed rape and faba bean straw comparing conversion without any pretreatment (untreated) and with a wet oxidation pretreatment step (WO)

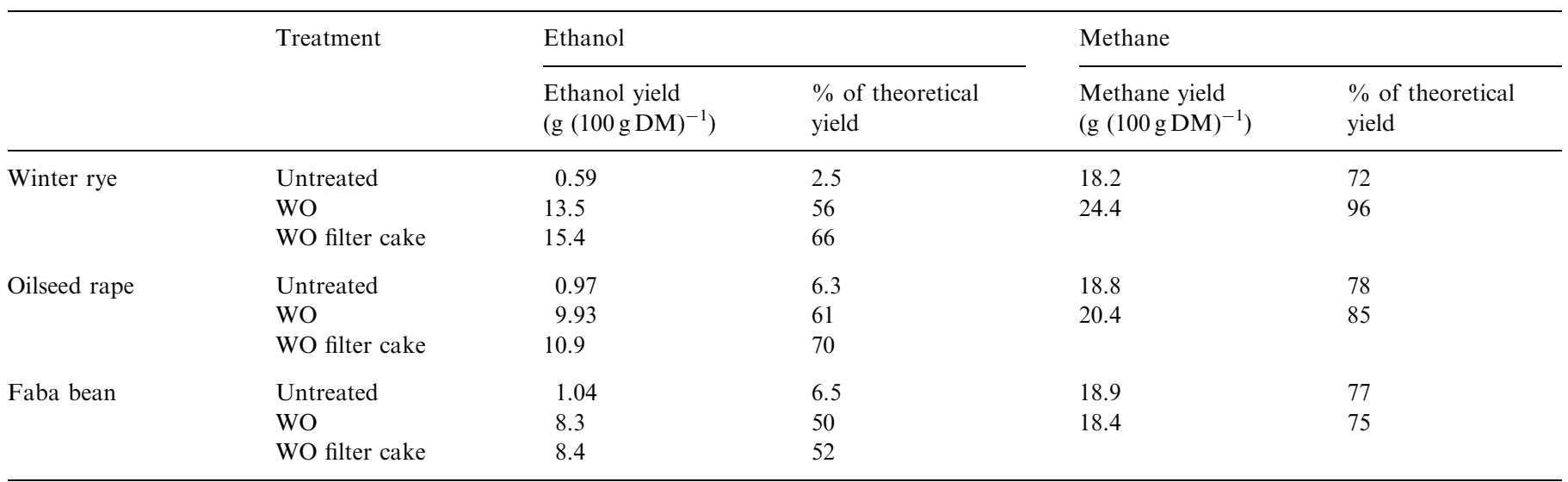

For ethanol, the yields are also reported for the WO filter cake where the solid and liquid fractions were separated by filtration. The theoretical ethanol yield was based on glucan content in the raw material and the theoretical methane yield was based on the assumption that the formula for volatile solids was $\mathrm{CH}_{2} \mathrm{O}$ and that the volatile solids was stoichiometrically converted into carbon dioxide and methane. 
sugar degradation and thus optimal pretreatment conditions can both increase sugar recovery as well as lower the formation of inhibitors.

Judging by the selection of present raw materials and the selected pretreatment conditions, biogas seems to be the most favorable product, compared with ethanol, primarily because of higher yields compared with the theoretically expected (Table 2). Pretreatment did not have a significant effect on biogas production from oilseed rape straw or faba bean straw, which simplifies the production and lowers the production cost and energy use. Biogas productivity was, however, rather low, but this was probably a result of acclimatization of the microorganisms and thus the productivity would be increased in a continuous process.

Ethanol has advantages over biogas e.g. since it is a liquid fuel that can readily be integrated into existing fuel supply systems and directly substitute fossil fuels in the transportation sector. In order to make an economically feasible process out of ethanol production, ethanol yields need to be as high as possible while production costs are kept as low as possible. The yield of ethanol could be increased, compared with what was found in this study, with optimized pretreatment conditions and if the microorganism used could convert the pentoses originating from the hemicellulose fraction into ethanol. From the raw material analysis, it can be concluded that the maximum theoretical ethanol yield based on all available sugars in e.g. winter rye is $38.20 \mathrm{~g}(100 \mathrm{~g})^{-1} \mathrm{DW}$. Another fact that will contribute to the ethanol production economy is that lignin is not affected in the process, but can be burned and the energy used in the process.

When evaluating faba bean and oilseed rape as potential bioenergy raw materials, additional agroecosystem services need to be included like break crop effects in cereal-rich rotations reducing the survival of nematode populations, suppressing leaf and root diseases such as take-all fungus, and reducing weeds $[20,23,24]$ and consequently reducing the potential need for pesticides diminishing pollution as well as indirect energy use.

It can be concluded that biogas can easily be produced from winter rye straw, oilseed rape straw and faba bean straw. However, biogas productivity has to be optimized to increase the gas production level. For production of ethanol, the pretreatment needs to be optimized and a strain or combination of strains or microorganisms should be used so that all sugars are effectively converted into ethanol. The selected present raw materials offer different services to the agroecosystems, and with the right local selection of crops and adaptation to the current crop production it seems promising for farmers to provide the society with biomass resource for energy production.

\section{Acknowledgments}

The authors are thankful to Mr. Tomas Fernqvist, Mrs. Ingelis Larsen and Dr. Anders Thygesen for technical assistance. This work was financially supported by Det strategiske Forskningsrad by the project 2104-06-0004Bio.REF: Biorefinery for sustainable reliable economical fuel production from energy crops.

\section{References}

[1] Midilli A, Dincer I, Ay M. Green energy strategies for sustainable development. Energy Policy 2006;34:3623-33.

[2] Wyman CE. Ethanol production from lignocellulosic biomass: overview. In: Wyman CE, editor. Handbook on bioethanol: production and utilization. Bristol: Taylor \& Francis; 1996. p. 1-18.

[3] Jacques K, Lyons TP, Kelsall DR. The alcohol textbook. 3rd ed. Trowbridge, Wiltshire: Redwood Books; 1999.

[4] Schmidt AS, Thomsen AB. Optimization of wet oxidation pretreatment of wheat straw. Bioresource Technology 1989;64:139-51.

[5] McGinnis GD. WWWMCE. Biomass pretreatment with water and high-pressure oxygen - the wet-oxidation process. Industrial \& Engineering Chemistry Product Research and Development 1983;22: 352-7.

[6] Galbe M, Zacchi G. A review of the production of ethanol from softwood. Applied Microbiology and Biotechnology 2002;59:618-28.

[7] Klinke FIB, Olsson L, Thomsen AB, Ahring BK. Potential inhibitors found from wet oxidation of wheat straw and their effect on ethanol production of Saccharomyces cerevisiae: wet oxidation and fermentation by yeast. Biotechnology and Bioengineering 2003;81:738-47.

[8] Olsson L, Hahn-Hagerdal B. Fermentative performance of bacteria and yeasts in lignocellulose hydrolysates. Process Biochemistry 1993;28:249-57.

[9] Gunaseelan VN. Anaerobic digestion of biomass for methane production: a review. Biomass \& Bioenergy 1997;13:83-114.

[10] Yadvika S, Sreekrishnan TR, Kohli S, Rana V. Enhancement of biogas production from solid substrates using different techniquesa review. Bioresource Technology 2004;95:1-10.

[11] Svensson LM, Christensson K, Bjornsson L. Biogas production from crop residues on a farm-scale level in Sweden: scale, choice of substrate and utilisation rate most important parameters for financial feasibility. Bioprocess and Biosystems Engineering 2006;29:137-42.

[12] Mayer J, Buegger F, Jensen ES, Schloter M, Hess J. Residual nitrogen contribution from grain legumes to succeeding wheat and rape and related microbial process. Plant and Soil 2003;255:541-54.

[13] Trinsoutrot I, Nicolardot B, Justes E, Recous S. Decomposition in field of residues of oilseed rape grown at two levels of nitrogen fertilisation. Effects on the dynamics of soil mineral nitrogen between successive crops. Nutrient Cycling in Agroecosystems 2000;56: 125-37.

[14] Varga E, Schmidt AS, Reczey K, Thomsen AB. Pretreatment of corn stover using wet oxidation to enhance enzymatic digestibility. Applied Biochemistry and Biotechnology 2003;104:37-50.

[15] Fox M, Noike T. Wet oxidation pretreatment for the increase in anaerobic biodegradability of newspaper waste. Bioresource Technology 2004;91:273-81.

[16] Scholz V, Ellerbrock R. The growth productivity, and environmental impact of the cultivation of energy crops on sandy soil in Germany. Biomass \& Bioenergy 2002;23:81-92.

[17] Venturi P, Venturi G. Analysis of energy comparison for crops in European agricultural systems. Biomass \& Bioenergy 2003;25: 235-55.

[18] Beaudoin N, Saad JK, Van Laethem C, Machet JM, Maucorps J, Mary B. Nitrate leaching in intensive agriculture in Northern France: effect of farming practices, soils and crop rotations. Agriculture Ecosystems \& Environment 2005;111:292-310.

[19] Crews TE, Peoples MB. Legume versus fertilizer sources of nitrogen: ecological tradeoffs and human needs. Agriculture Ecosystems \& Environment 2004;102:279-97.

[20] Jensen ES, Hauggaard-Nielsen H. How can increased use of biological $\mathrm{N}_{2}$ fixation in agriculture benefit the environment? Plant and Soil 2003;252:177-86. 
[21] Hansen TL, Schmidt JE, Angelidaki I, Marca E, Jansen JL, Mosbaek $\mathrm{H}$, et al. Method for determination of methane potentials of solid organic waste. Waste Management 2004;24:393-400.

[22] Thomsen MH, Thygesen A, Jørgensen H, Larsen J, Christensen BH, Thomsen AB. Preliminary results on optimization of pilot scale pretreatment of wheat straw used in coproduction of bioethanol and electricity. Applied Biochemistry and Biotechnology 2006;129-132: 448-60.
[23] Kirkegaard JA, Sarwar M. Biofumigation potential of brassicas-I. Variation in glucosinolate profiles of diverse field-grown brassicas. Plant and Soil 1998;201:71-89.

[24] Stevenson FC, vanKessel C. A landscape-scale assessment of the nitrogen and non-nitrogen rotation benefits of pea. Soil Science Society of America Journal 1996;60(6):1797-805. 